\title{
MOURNING GROUND-WARBLER.
}

\author{
+ Trichas Philadelphia, Wils.
}

\section{PLATE CI.-MALE.}

Although this beautiful species has been met with in various portions of our eastern maritime districts, it cannot be said to be an abundant one; and no one has, as yet, been able to discover its nest. Several of my ornithological friends have supplied me with specimens procured in the neighbourhood of New York, Philadelphia, and in the mountainous parts of Vermont; all these were found during the spring and summer months, none having been seen during the autumn; where, on the contrary, the Connecticut Warbler is plentiful.

The habits of the Mourning Warbler resemble, considerably, those of the Maryland Yellow-throat, and other birds of the genus trichas, keeping in low thickets, among the branches of which it hops, as well as on the ground. Its flight also resembles that of the bird above mentioned. So curiously and cautiously does it pass from south to north, and from north to south, that its migratory movements have eluded the most attentive observers. My friend the Rev. John Bachman never has seen it in South Carolina; and in one instance only, have I met with it in Louisiana. The figure represents a fine adult male in perfect plumage.

Mourning Warbler, Sylvia Philadelphia, Wils. Amer. Orn., vol. ii. p. 101.

Sylvia Philadelphia, Bonap. Syn., p. 85.

Mourning Wareler, Sylvia Philadelphia, Nutt. Man., vol. i. p. 404.

Mourning Warbler, Sylvia Philadelphia, Aud. Orn. Biog., vol. v. p. 79.

Bill short, straight, conico-subulate, compressed toward the end, acute; upper mandible with the dorsal line declinate, straight, a little convex at the end, the ridge narrow, the sides convex, the edges direct and overlapping, with a slight notch, the tip narrow; lower mandible with the angle of moderate length and narrow, the dorsal line ascending and slightly convex, the sides rounded, the edges inflected, the tip acute; the gape-line straight. Nostrils basal, lateral, operculate, exposed.

Head of moderate size, ovato-oblong; neck short; body rather slender; feet rather long; tarsus slender, longer than the middle toe, much compressed, covered before with seven scutella, behind with two longitudinal plates 

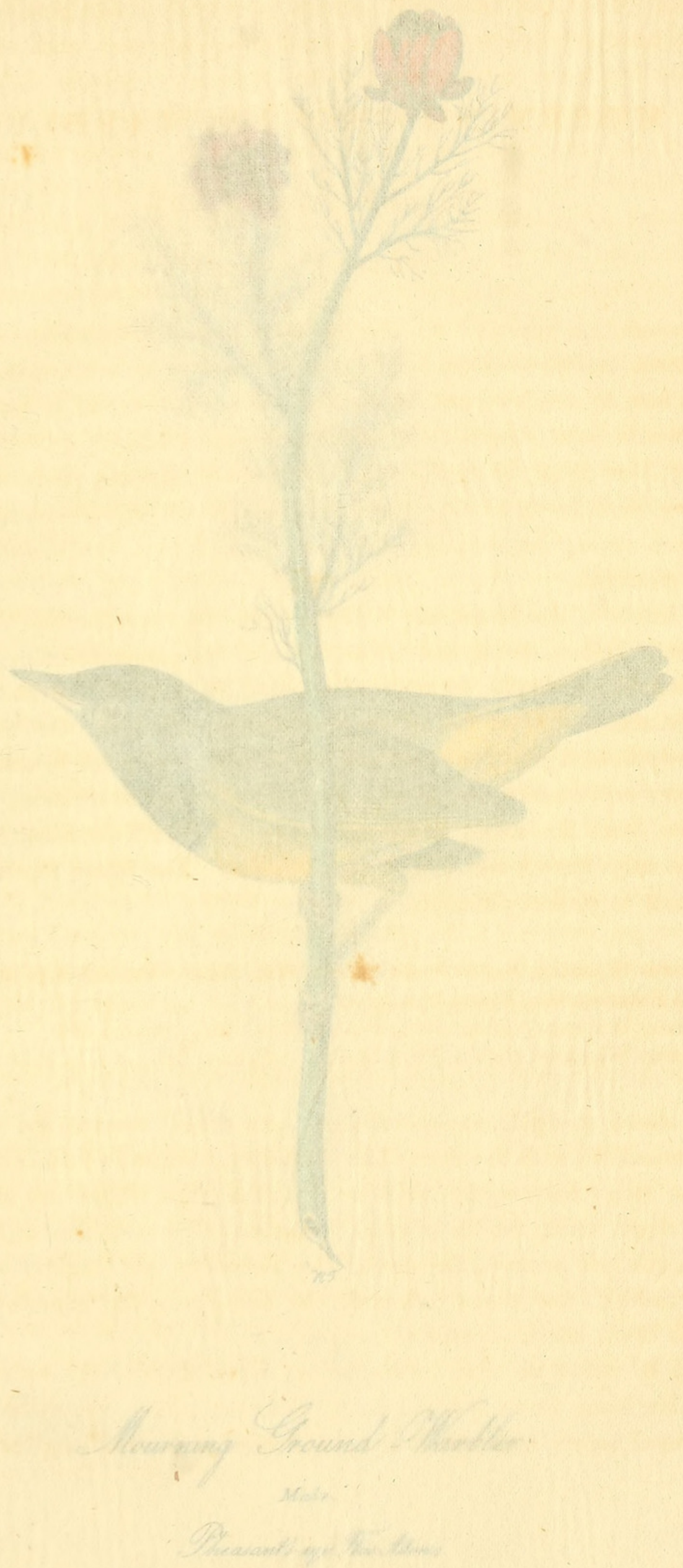
Althrugh wain fontifial speeies has been met with, in various portions of onr eastern maritime districts, it cannot be said to be an abundant one; and no one bas, as yet; been able to discover its nest. Severad of my omithological friends have supplied ine with specimens procured in the neighbourhood of New York, Philadeliphin; and in the moultainoss parts of Vermont; ant these were found during the springs and summor months, none having

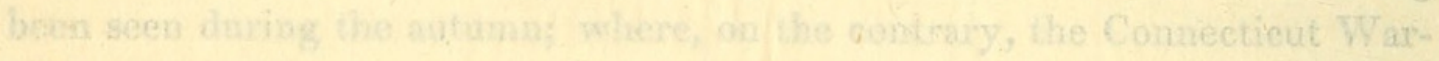
bler is plentifor.

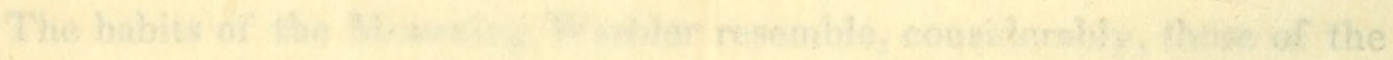

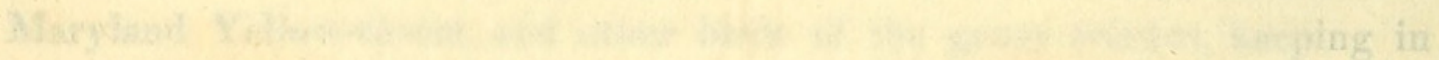

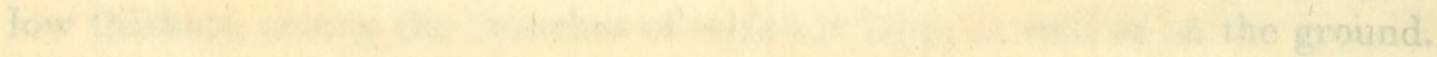
14. whe and

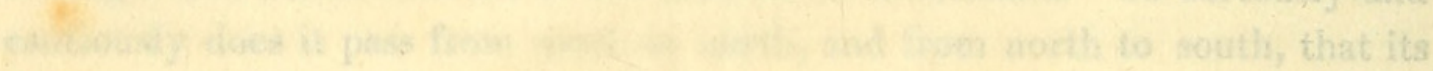
vaigratory movergenth hat 6he Pev. Jomx Dasenanaw was sechn if in South Carolina; and in one instamec only, have 1 met with it in Lowislanas. The figure represents a fine adiult male in porfeet plumage.

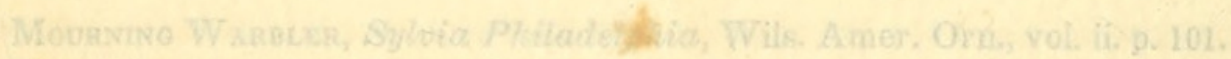

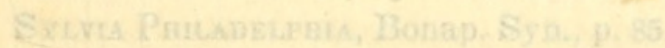

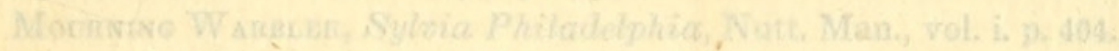

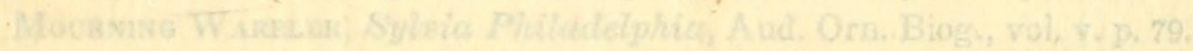

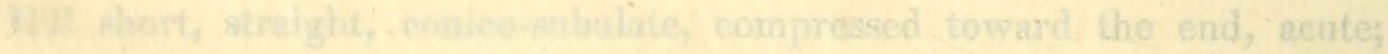

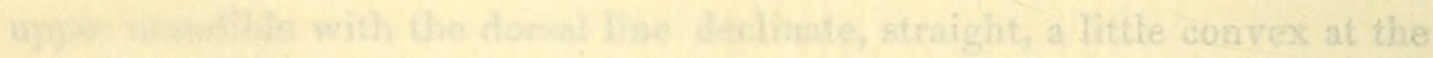

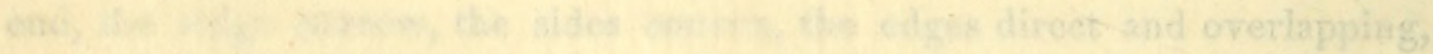

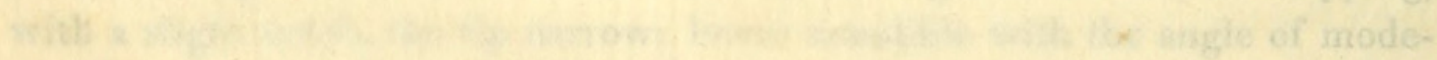
rath kenatar a

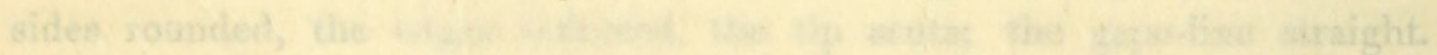
Xostrils basal, lateral,

Head of modornte aizon ? a thender;

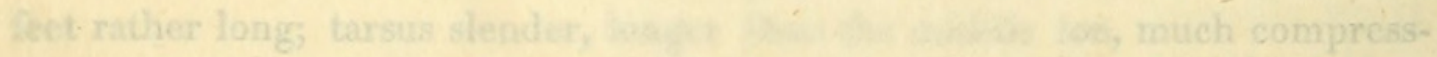

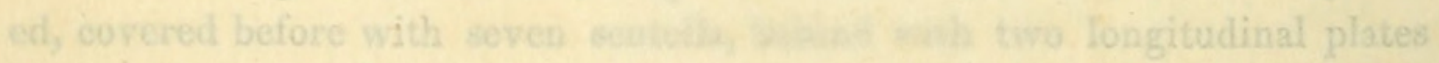




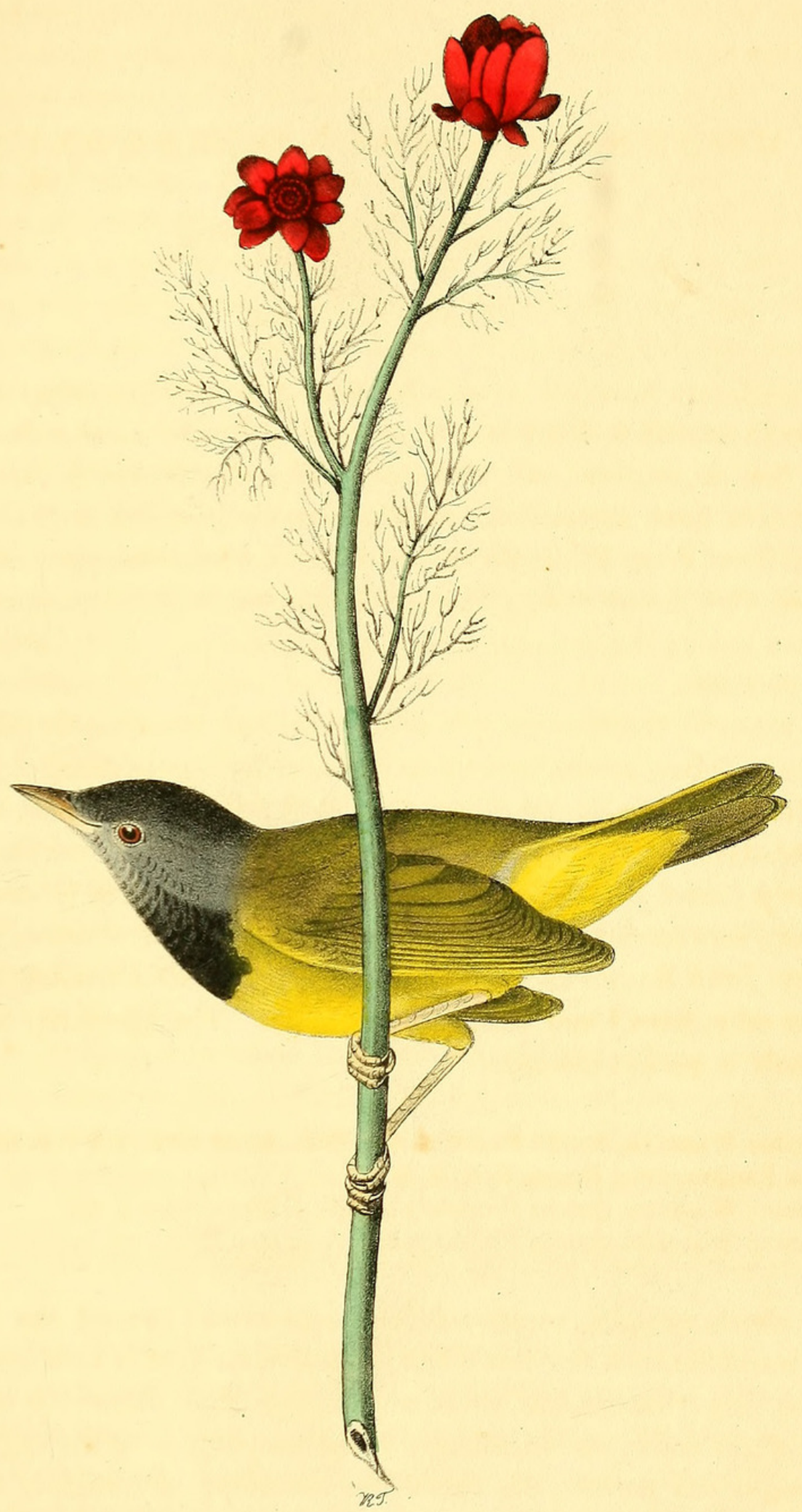

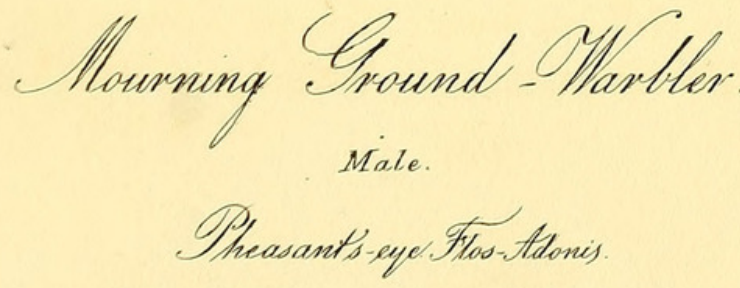



meeting so as to form a thin edge; the lateral toes meeting so as to form a thin edge; the lateral toes nearly equal, the third much longer, and united at the base to the fourth, hind toe stronger and rather large; claws moderately arched, extremely compressed, laterally grooved, acute.

Plumage soft and blended, with little gloss; wings of moderate length, somewhat concave; the second, third, and fourth primaries having the outer web cut out toward the end; the second quill is longest, the third scarcely a quarter of the twelfth of an inch shorter, the fourth half a twelfth shorter than the third, and a quarter of a twelfth shorter than the first; the other primaries slowly graduated, the longest or second being only eight and a half twelfths longer than the first secondary. All the quills, primary as well as secondary, are rounded; and there are only nine primaries. Tail rather long, considerably rounded, the lateral feathers a quarter of an inch shorter than the middle, which are longest; all the feathers rather narrow and obliquely pointed.

Upper mandible brownish-black, its edges in their whole length pale yellowish flesh-colour, as is the lower mandible, which, however, is a little dusky at the end. Iris hazel. Feet and claws flesh-coloured. The upper part of the.head, the hind part and sides of the neck, are deep ash-grey, tinged with blue; the back, scapulars, and rump deep olive-green; the wings and tail greyish-brown, the edge of the wing and the outer margin of the first quill bright yellow, the other primaries narrowly edged with greenishyellow, the secondaries of a paler brown externally, as are the tail-feathers. From the ridge of the upper mandible to the eye is a rather broad band of black, which extends a little way under the eye, but is not nearly so conspicuous as that of the species above described; nor are the eyelids marked with white, their marginal feathers being all dusky grey. The fore part of the neck and a portion of the breast, to the distance of an inch and five-twelfths from the bill, are deep black, with lunulate white markings, each feather being margined with that colour; the white edges of the lower black feathers being extremely narrow leave a crescent of nearly pure black; the breast, abdomen, lower tail-coverts, and lower wing-coverts are bright yellow, the sides of the body yellowish-green.

Length to end of tail 5 inches; "extent of wings 8;" bill along the ridge $\frac{5}{1} \frac{1}{2}$, along the edge of lower mandible $\frac{7 \frac{7}{12}}{2}$; wing from flexure $2 \frac{7}{12}$; tail $2 \frac{1}{12}$; tarsus $\frac{9}{12}$; hind toe $\frac{3 \frac{1}{4}}{12}$, its claw $\frac{3}{1} \frac{1}{2}$; middle toe $\frac{6}{12}$, its claw $\frac{2 \frac{1}{2}}{12}$.

Flos-Adonis.

Adonis autumnalis, Linn. Sp. Pl., p. 771. Willd. Sp. Pl., vol. ii. p. 1304. Smith. Engl. Fl., vol. iii. p. 43.-Polyandria Pentagynia, Linn.-Ranunculacee, Juss.

VOL. II. 


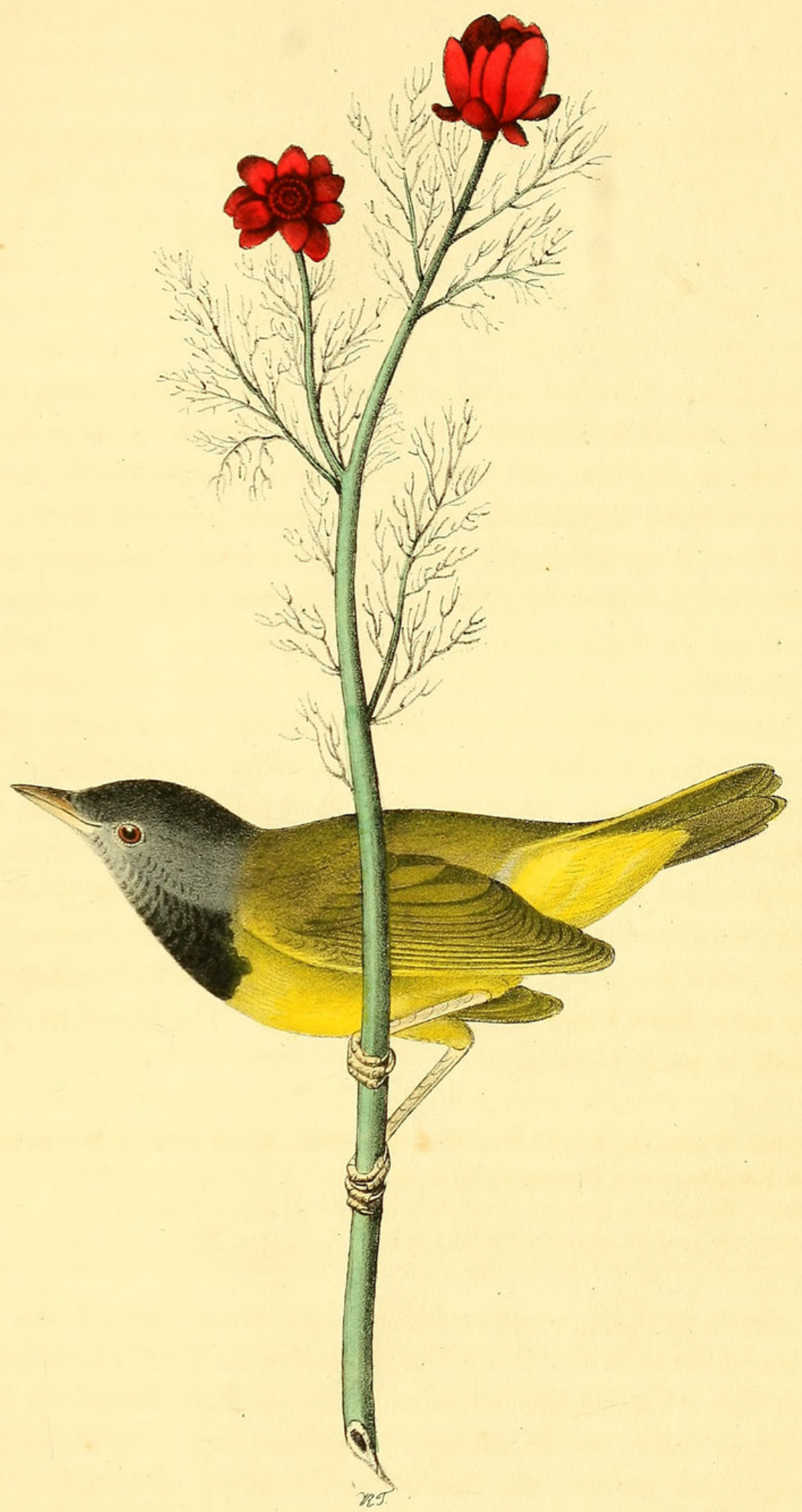

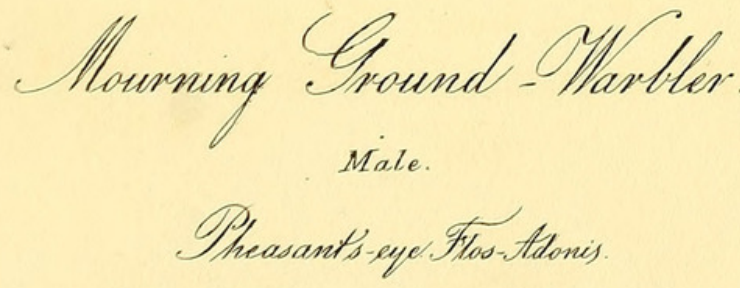




\section{$2 \mathrm{BHL}$ Biodiversity Heritage Library}

Audubon, John James. 1841. "Mourning Ground-Warbler, Sylvicola philafelphia, Wils. [PI. 101]." The birds of America: from drawings made in the United States and their territories 2, 76-77. https://doi.org/10.5962/p.319214.

View This Item Online: https://www.biodiversitylibrary.org/item/124834

DOI: https://doi.org/10.5962/p.319214

Permalink: https://www.biodiversitylibrary.org/partpdf/319214

\section{Holding Institution}

Smithsonian Libraries

\section{Sponsored by}

Biodiversity Heritage Library

\section{Copyright \& Reuse}

Copyright Status: NOT_IN_COPYRIGHT

This document was created from content at the Biodiversity Heritage Library, the world's largest open access digital library for biodiversity literature and archives. Visit BHL at https://www.biodiversitylibrary.org. 